\title{
Influence of meteorological events on obstetrical data in cattle and swine
}

\author{
M. B. Dickie ${ }^{1}$, P. Sabo ${ }^{2}$ and A. Schaller ${ }^{3}$ \\ ${ }^{1}$ Clinic of Obstetrics, Gynaecology and Andrology, University of Veterinary Medicine, Vienna, Austria; \\ ${ }^{2}$ Central Institute for Meteorology and Geodynamics, Vienna, Austria; and ${ }^{3}$ Second Department of \\ Obstetrics and Gynaecology, University of Vienna, Austria
}

\begin{abstract}
In an interdisciplinary scientific cooperation involving human and veterinarian obstetricians and meteorologists, an attempt was made to correlate the obstetrical data of cows and pigs with meteorologically defined weather events. During the observation period of 10 years the parturitions of cattle $(n=645)$ showed no significant statistical connection to the weather on day of delivery, the day before parturition or the day after. The only significant result in cattle was a shortening of the gestation period by 4.9 days in a group of cows that went into labour on, or after, the sixth day of a constant weather situation. Significant variations in the duration of gestation in swine $(n=786)$ were related to the weather on the day of delivery; central high-gradient anticyclonic spring, summer and autumn weather was linked to an extension of the pregnancy by nearly 1 day, while cyclonic central low-gradient weather during autumn was related to a shortening of pregnancy by approximately 1 day. The weather on the day before parturition was also correlated with the duration of gestation in swine. In this respect, low-gradient cyclonic autumn weather coincided with gestation periods that were reduced by 0.95 days, while central anticyclonic winter and spring weather coincided with extensions of gestation of 0.98 and 1.12 days, respectively. Compared with labour during low-gradient anticyclonic weather, the course of labour in pigs was significantly protracted by approximately $1.5 \mathrm{~h}$ during low-gradient cyclonic weather. Weather fronts on the day before, the day after or on the day of labour had no influence on the gestation and parturition data collected in either species.
\end{abstract}

\section{Introduction}

Giving birth to their offspring on time is of crucial importance in domestic animals. Deviations from the expected time of parturition of only a few days have negative effects on both the offspring and the mother (immature fetus, retentio secundinarum) (Grunert, 1983; Arthur et al., 1989).

Schaller et al. (1985) showed a positive correlation between the frequency of births in humans and four [anticyclonic (a) weather in winter, cyclonic (c) weather in spring and summer, and no definite pressure gradient $(G)$ in summer] out of 24 distinguishable weather conditions on the day of birth (see Table 1). Furthermore, Schaller et al. (1989) found a relationship between the EPH-gestosis (oedema, proteinuria and hypertension) and the weather. Anticyclonic, central (K) winter weather and cyclonic current $(C)$ autumn weather were associated with more cases of gestosis exhibiting oedema or proteinuria, while cyclonic, central summer weather was found to coincide with more threatening symptoms of gestosis (preeclampsia and eclampsia). An attempt was therefore made to determine whether there is a meteorological influence on the time and course of labour in domestic animals.
Only domestic animals that demonstrate no seasonal behaviour (cattle and swine) were used, so that data would not be concentrated at specific times of the year.

The hormonal phenomena occurring before parturition are similar in both cattle and swine (Hoffmann et al., 1977). Progesterone is very important for maintaining pregnancy, its major source is the corpus luteum in both species. In cows, the removal of the ovaries during the last third of pregnancy usually results in an abortion, although this may be delayed for up to 75 days (Lindell et al., 1981). Ovariectomy does, however, lead to a fall in progesterone indicating that the ovary is the primary source (Lindell et al., 1981; Wendorf et al., 1983). A slight and gradual decrease in the concentration of progesterone occurs during the last trimester of gestation; the concentration then falls rapidly about $30-40 \mathrm{~h}$ before parturition (Stabenfeld et al, 1970; Ash et al., 1973; Robertson and King, 1974; Watts et al., 1988; Eissa and El-Belely, 1990).

In the hormonal cascade initiating labour, the corticosteroids are of major importance. As the fetus matures, glucocorticoids accumulate: this starts approximately 10-20 days before birth in cows (Comline et al., 1974; Hoffmann et al., 1977) and even as early as 40 days before delivery in swine (First and Bosc, 1979). Eissa and El-Belely (1990) suggested that the abrupt increase in the concentration of corticosteroids on the sixth day 
Table 1. Concise synoptic characterization of the six types of weather situations observed during the four meteorologically defined seasons

\begin{tabular}{|c|c|}
\hline Season & Characteristics of weather \\
\hline $\mathrm{aC}$ & $\begin{array}{l}\text { General characteristics: broken or scattered clouds; no precipitation; lively winds; diminishing vertical } \\
\text { movements; negative vorticity }\end{array}$ \\
\hline Spring & Friendly; already frequent quite high temperatures for the season; strong warming during the day \\
\hline Summer & Sunny and very warm or hot; no thunderstorms or heat lightning \\
\hline Autumn & Sunny and friendly; frequently quite cool in the morming \\
\hline Winter & Mild; temperatures frequently above average \\
\hline $\mathrm{aK}$ & $\begin{array}{l}\text { General characteristics: scattered clouds; frequently clear weather; no precipitation; light winds; } \\
\text { diminishing movements of air and negative vorticity }\end{array}$ \\
\hline Spring & In the early mornings frequently still quite frosty, with sun and strong warming later \\
\hline Summer & Hot; scattered clouds; often clear but hazy \\
\hline Autumn & Often foggy in the morning; mostly sunny throughout the day and often still quite warm \\
\hline Winter & Cold; frequently constant low stratus \\
\hline $\mathrm{aG}$ & $\begin{array}{l}\text { General characteristics: frequently little cloud cover; usually no precipitation; light winds; mostly only } \\
\text { weak distinctive diminishing vertical movements as well as negative vorticity }\end{array}$ \\
\hline Spring & Friendly and quite mild throughout the day; in the morning often still slight frost \\
\hline Summer & Sunny and hot, sometimes even sticky; low tendency towards thunderstorms \\
\hline Autumn & In the early morning often foggy; throughout the day friendly and still warm \\
\hline Winter & Mostly constantly foggy or overcast; often constant low stratus \\
\hline $\mathrm{cC}$ & $\begin{array}{l}\text { General characteristics: rapidly changing; mostly broken clouds; frequent precipitation; lively to stormy } \\
\text { winds; mostly rising vertical movements and positive vorticity }\end{array}$ \\
\hline Spring & Unstable and cool; often wet, cold and windy \\
\hline Summer & Unfriendly and very cool; frequently passages of fronts accompanied by formation of thunderstorms \\
\hline Autumn & Variable; often cool, frequent change of air masses \\
\hline Winter & $\begin{array}{l}\text { Unfriendly, in western current situations temperatures often much too high for the season, often } \\
\text { during long periods }\end{array}$ \\
\hline $\mathrm{cK}$ & $\begin{array}{l}\text { General characteristics: often overcast or broken clouds; precipitation (sometimes lasting for long } \\
\text { periods); weak movements of air, predominantly rising vertical movements; positive vorticity }\end{array}$ \\
\hline Spring & Rainy; often too cool for the season \\
\hline Summer & Often definitely bad weather; temperature considerably below average \\
\hline Autumn & Unfriendly; wet and cold weather \\
\hline Winter & Often only moderately cold; frequent precipitation in form of rain \\
\hline$c G$ & $\begin{array}{l}\text { General characteristics: variable or broken clouds; frequent precipitation; light winds; mostly rising } \\
\text { vertical movements and positive vorticity }\end{array}$ \\
\hline Spring & Unfriendly; rather cool \\
\hline Summer & High tendency towards thunderstorms; only moderately warm \\
\hline Autumn & Frequent early morning fog; changing and cool weather throughout the day \\
\hline Winter & Too mild but rather unstable weather for the season \\
\hline
\end{tabular}

a: anticyclone; c: cyclone; C: current (dynamic) weather situation; G: weather situation of no defined pressure gradients; K: central weather situation.

before parturition plays a fundamental role in inducing parturition in cows. The glucocorticoids stimulate an increased secretion of placental oestrogens. The concentration of oestrogen rises within the last 3 weeks of gestation in cows (Robertson, 1974) and within the last week of gestation in sows (Edqvist et al., 1973; Robertson and King, 1974). The uterus reacts to the influence of oestrogen by producing prostaglandin (Pimentel et al., 1986). The effects of prostaglandin on the hormonal cascade are unclear. Its luteolytic action during the cycle and pregnancy has been proven (Diehl ef al., 1977), but at term the rise in prostaglandin concentration follows rather than precedes the fall in progesterone concentration (Randall et al., 1986; Watts et al., 1988). Prostaglandin $\mathrm{F}_{2 \mathrm{a}}$ is also closely connected to the myometrial activity at parturition (Randall, 1990). Providing the endocrine changes described above have taken place, the uterus is also able to react to oxytocin. The ability of the myometrium to respond to oxytocin at term does not only require a decrease in the concentration of progesterone in the peripheral blood but probably also a decrease in the relaxin concentration (Watts et al., 1988). The function of relaxin is not yet known. Its role in pregnancy protection on the one hand (Watts et al., 1988) and its participation in luteolysis and parturition on the other (Nara et al., 1982; Musah et al., 1987; Caldwell et al., 1990) have been described.

All of the events described above provide an endocrine environment necessary for the activation of the myometrium; the oestrogen:progesterone ratio is probably responsible for increasing the concentration of oxytocin receptors (Wendorf et al., 1983), and oestrogen itself (Fitz, 1981) may cause an increase in the number of adrenergic receptors. Finally, $24-48 \mathrm{~h}$ before parturition, the uterus reacts to oxytocin stimulation and 
is also responsive to environmental influences via the vegetative nervous system (Rüsse, 1965; Naaktgeboren and Bontekoe, 1976; Fitz, 1981). The activation of the sympathoadrenal system relaxes the longitudinal and vertical unstriped muscles of the uterus and the vagina so that the birth canal can form. An increase in the secretion of catecholamines slows down or interrupts parturition altogether (fight and flight syndrome); this effect is exploited in the application of $\beta$-sympathomimetic substances to treat pre-term uterine motility (Arbeiter and Holler, 1980; Zerobin and Kündig, 1980; Kiesling et al., 1987). The uterus also receives some parasympathetic fibres from the sacral outflow and there is evidence that cholinergic fibres have a role in the control of uterine motility. Rüsse (1965), Naaktgeboren and Slijper (1970) and Naaktgeboren and Bontekoe (1976) suggested that the parasympathetic-cholinergic system controls contraction and is responsible for the expulsion of the fetus against the resistance of the maternal tissue.

In cows and sows the first stage of labour requires on average $3-4 \mathrm{~h}$, with contractions occurring at intervals of $15 \mathrm{~min}$. The expulsion period usually takes $0.5-4 \mathrm{~h}$ in both species (Clegg, 1959). In cows, the placental stage (from parturition to the complete discharge of the placenta) is completed on average within $6 \mathrm{~h}$ (Grunert, 1993). In sows, this period cannot be defined since several placentae can be discharged between births of the individual piglets.

\section{Materials and Methods}

\section{Animals and treatments}

This report covers the period between 1 January 1980 and 31 December 1989. Both the cattle and the swine were kept at the scientific farm of the Veterinary University of Vienna in Merkenstein-Berndorf. Cows were stabled there in short standings, and were transferred for calving to long standings within the same building 14 days before the end of gestation. Sows were kept in completely airconditioned stables in single pens, and were transferred to farrowing pens 14 days before the date calculated for parturition.

Throughout the reviewed period both species were fed according to their condition. Parturitions were studied in Austrian Brown cattle $(n=645)$ and in German Large White sows $(n=786)$; in both groups the figures were adjusted to exclude induced parturitions, dystocia and surgical sections. For both groups the breed was preselected; the 645 calves were sired by 26 bulls and the 786 litters of piglets by 49 boars. The average duration of the gestation period in the cattle was 287.1 days and in the swine 114.7 days.

The decisive factor for the correlation between parturition and weather was the difference between the precalculated and the actual date of delivery. Known data for the cattle were the days of insemination, the precalculated date of delivery, the actual duration of gestation and the duration of the placental stage (i.e. the period from delivery of the calf to the complete discharge of the placenta). In this respect, only the 484 cows with a placental period between 0 and $11 \mathrm{~h} 59 \mathrm{~min}$ (which was the tolerated duration of the placental stage) were included, because thereafter treatment with oxytocin and antibiotics started. Known data for the sows were the dates of insemination, the precalculated dates of parturition, the actual duration of gestation, the duration of the expulsion period, and the numbers of piglets born (alive or stillborn).

These obstetrical parameters were correlated with the daily weather patterns during the 10 years of study, according to six weather situations and four seasons (giving a total of 24 possible weather situations). The basis for the distinction between weather patterns is a classification according to three general weather situations, central situations $(\mathrm{K}$; with a low or a high pressure area near the surface), current (dynamic) situations ( $C$; characteristically with lively winds), and situations of no defined pressure gradient (G; no winds); each of these general situations is influenced by two classes of weather situation, cyclone ( $c$; overcast or very cloudy, often with precipitation) or anticyclone (a; clear sky or scattered clouds with no precipitation) (see Table 1). Throughout the surveyed period, the weather of Vienna and its environs as well as of Austria and the eastern Alps were classified by the same person.

\section{Characterization of weather}

The characterization of the weather was based mainly on the 'Daily Weather Chart of the Central Institute for Meteorology and Geodynamics' (Täglicher Wetterbericht der Zentralanstalt für Meteorologie und Geodynamik) and the daily upper air measurements of the radiometeorograph Vienna - Hohe Warte (international meteorological identification number 11035) (Adiabatenblätter, Teil A; 1980-1989). The Meso-scale gamma is climatologically and statistically based on the climate and the bioclimate of Vienna as studied by Steinhauser et al. (1955, 1957).

\section{Statistical analyses}

Owing to the large amount of data, a main frame with SAS software (Statistical Analysing System) was used for purposes of analysis, which produced a print-out of 96000 lines. Several statistical procedures were applied. (1) In the case of a normal distribution within the respective group (e.g. hour of parturition) the chi-squared test was used (SAS; procedure frequency). (2) The Kruskal-Wallis test and Rank Score test were used to analyse an abnormal distribution within a group (SAS; procedure NPAR I WAY). (3) In the case of a significant result, Duncan's multiple-range test was used to specify the individual subgroup [SAS; procedure general linear models (GLM)].

When considering the daily weather conditions and frontal passages, all statistical approaches were done for the day before, the day after and the day of parturition. For reasons of clarity and because of the large amount of data obtained, only statistically significant results $(P<0.05)$ and the most interesting results with respect to correlations between the daily weather and the dates of parturition are given.

\section{Results}

Table 1 is a short synoptic characterization of the six general weather situations according to their seasonal variations in 
(a)

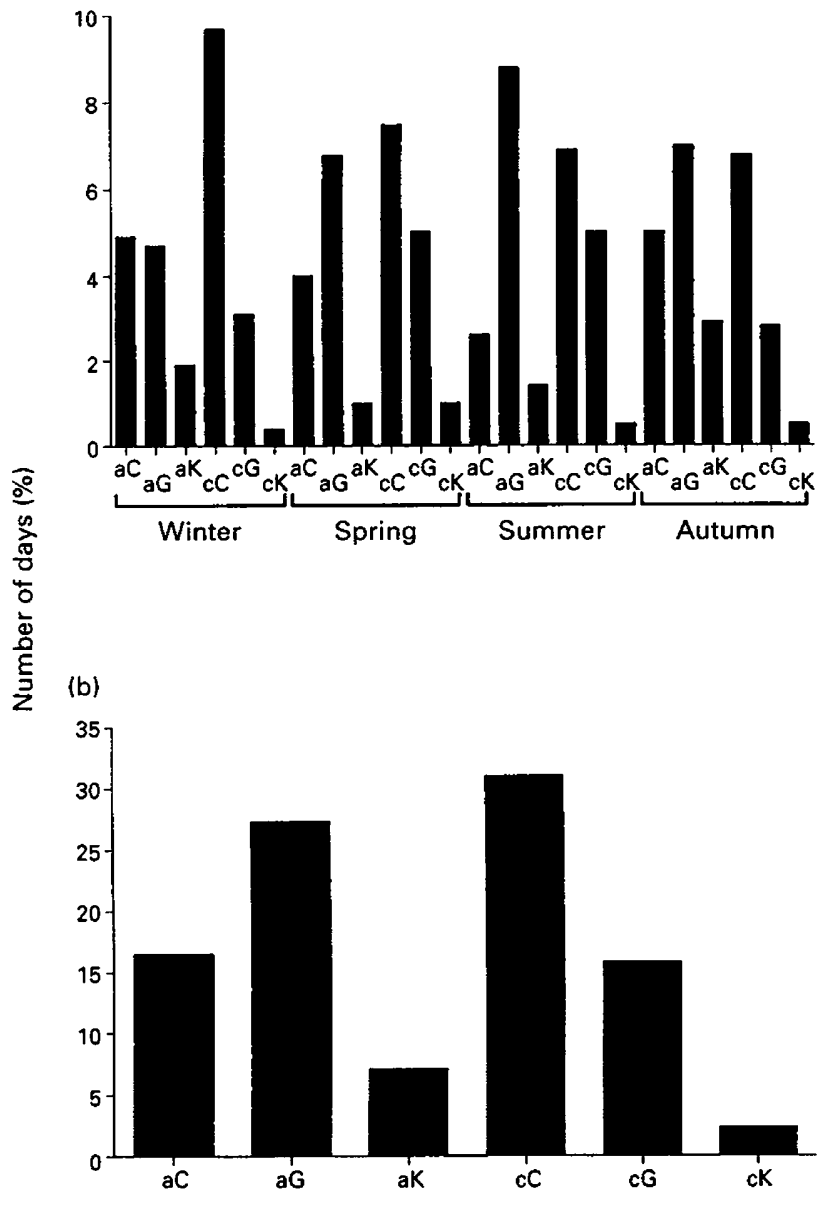

Fig. 1. The relative distribution of the weather situations (Table 1) (a) with and (b) without consideration of the four seasons during the 10 years of observation in this study. a: anticyclone; c: cyclone; C: current (dynamic) weather situation; G: weather situation of no defined pressure gradients; $\mathrm{K}$ : central weather situation.

Meso-scale alpha (Orlansky, 1975; Randerson, 1976). Figure 1 shows the relative distribution of the weather (i.e. the percentage of days related to a specific weather condition) during the 10 years of observation.

\section{Parturition in cattle}

Correlation of dates of parturition with individual weather situations. In comparing the dates of parturition during the three general weather situations, those parturitions that coincided with general weather situations of type $K$ were extended on average by 1.6 days (Fig. 2a), while the timing of parturitions during general weather situations of types $C$ and $G$ was shortened by 0.15 days and 0.7 days, respectively. The probability of error was slightly below 10\% (chi-squared test, $P<0.1$; Kruskal-Wallis, $P<0.09$; see Fig. 2).

Correlation of the weather situation with the duration of gestation. Animals were assigned to three groups according to the timing of gestation: (1) gestation reduced by more than (a)

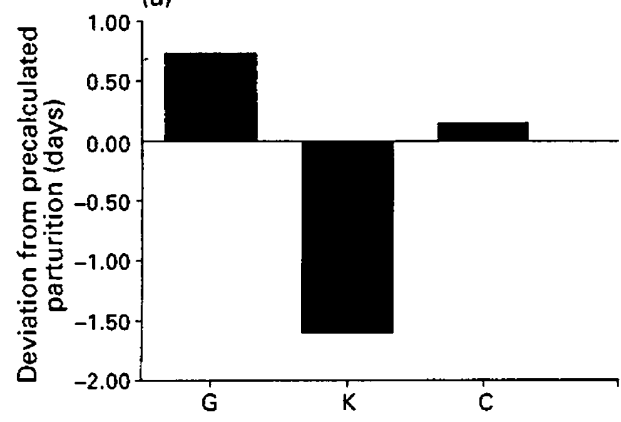

(b)

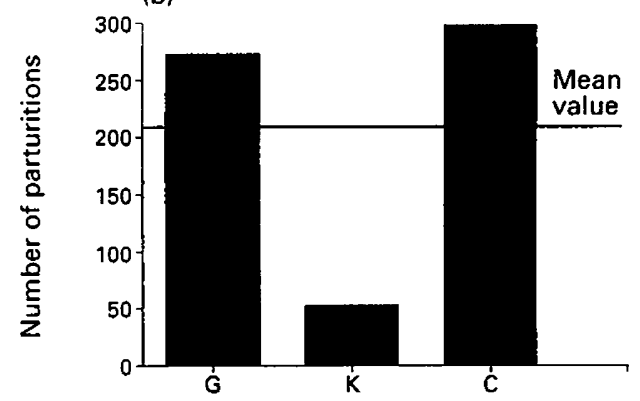

Fig. 2. The mean deviation from the precalculated to the actual date of parturition in cattle when the general weather situations (Table 1 ) during parturition were considered. (a) High deviation from the calculated date of parturition and (b) the absolute distribution of cow parturitions among the three general weather situations (the negative area indicates a prolonged gestation). $C$ : current (dynamic) weather situation; G: weather situation of no defined pressure gradients; $\mathrm{K}$ : central weather situation.

I day; (2) average gestation reduced or extended by 1 day; and (3) gestation extended by more than 1 day. Correlations between these groups and the weather situations were evaluated for the 24 individual or six grouped weather situations (Table 1), for the three general weather situations C, G and $K$, and also for the passage of weather fronts. All these approaches resulted in no statistically supported correlation being found. When correlation between gestation and placental stage was assessed, cattle with gestation periods reduced by $>3.8$ days had longer placental periods. Consequently, a study of two groups of gestation periods on the one hand [(1) gestations reduced by 3 days, and ( 2 ) all other gestation periods], and the weather situations on the other hand was made. Cyclonic $\mathrm{K}$ and anticyclonic $K$ weather situations in this model were significantly less connected to reductions in gestation periods and more to parturitions in group (2) (i.e. pregnancies that were reduced by up to 3 days, animals with parturition on time, or gestation periods longer than average) than the other four weather situations $(P<0.05)$. The highest percentage of parturitions with durations of gestation according to group (I) (i.e. a reduction of the gestation period by $>3$ days) occurred during anticyclonic $C$ weather situations, but without statistical support. Central $(\mathrm{K})$ weather situations (cyclone and anticyclone together) were linked significantly less to shortened periods of 
gestation [group (1)] and significantly more to parturitions on time, as well as to extended periods of gestation [group (2)], $(P<0.005)$ than expected.

Passages of fronts during parturition did not affect the duration of gestation. In cattle the weather situation on the day before or after parturition had no statistically supported influence on gestation. The same was also true for the passage of a front.

The number of parturitions in cattle was independent of the duration of a particular weather situation; neither preference for nor aversion to short- or long-term weather situations, respectively, could be proved. In the case of weather situations lasting for several days, there was no indication of preference for or an aversion to a particular day of the weather period (i.e. the number of parturitions expected on a defined day corresponded to the actual number of parturitions).

Correlation of the duration of weather situations with the duration of gestation. Animals were assigned to two groups: (1) parturitions between the first and the fifth day of a constant weather situation; and (2) parturitions on or after the sixth day of a constant weather situation. Parturition in group (1) deviated from the forecast date of parturition by only 0.1 days, thus being approximately equivalent to a parturition on time. This is significantly different $(P<0.001)$ from a reduction of 4.9 days in the gestation period of animals $(n=49)$ in group (2).

\section{Parturition in swine}

Correlation of dates of parturition with individual weather situations. The average gestation period of those sows that farrowed during cyclonic $\mathrm{K}$ autumn weather was 0.93 days shorter than that of the total group. The duration of gestation of those pigs with parturition during anticyclonic $\mathrm{K}$ spring, summer and winter weather was lengthened by $0.93,0.96$ and 0.98 days, respectively (Fig. 3). These two groups, which farrowed during cyclonic autumn weather or during anticyclonic $K$ spring, summer or winter weather situations, were significantly different in the duration of gestation $(P<0.05)$.

Evaluation of parturitions in swine after having divided the weather situations into cyclonic and anticyclonic groups during the four seasons only (i.e. a total of eight groups of weather situations) led to a statistically supported distinction between the period of gestation for swine that farrowed in cyclonic summer weather classes (average period was 0.35 days less than the precalculated time) and those animals that farrowed during cyclonic spring weather classes (average period was 0.34 days more than the precalculated time) $(P<0.05)$

Correlation of the weather situation with the duration of gestation. The sows were divided into two groups: (1) with a gestation period of $\geq 115$ days and (2) with a gestation period of $\leq 114$ days. More parturitions occurred during anticyclonic winter weather after a gestation period of $\geq 115$ days than after a gestation period of $\leq 114$ days. The overall average gestation period in anticyclonic winter weather was signifi- (a)

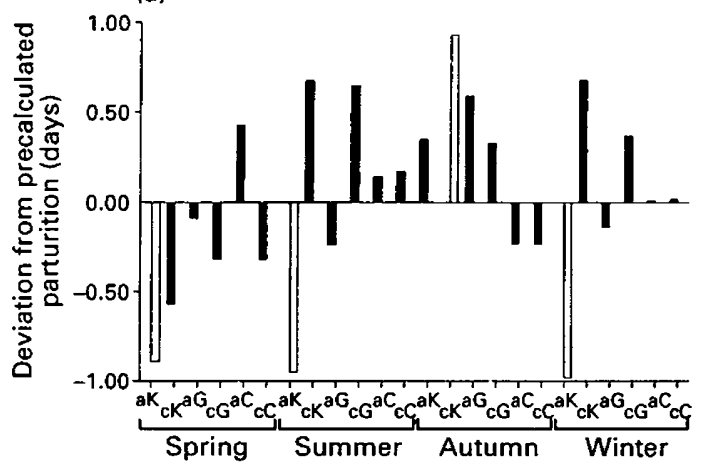

(b)

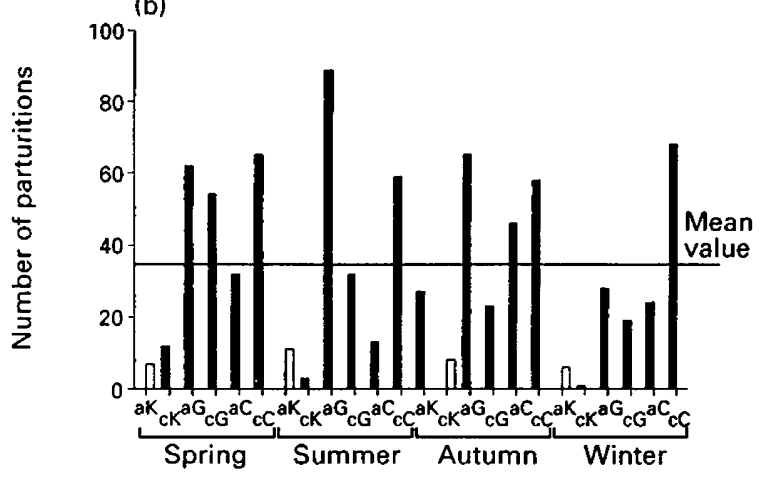

Fig. 3. The mean deviation from the precalculated to the actual date of parturition in swine when the individual weather situations (Table 1) during parturition were considered. (a) The open columns indicate a significant deviation from the calculated date of parturition in swine, while the closed columns indicate no statistical significance. (b) The absolute distribution of swine parturitions among the individual weather situations (the negative areas indicate a prolonged gestation). a: anticyclone; c: cyclone; C: current (dynamic) weather situation; G: weather situation of no defined pressure gradients; $\mathrm{K}$ : central weather situation

cantly greater $(P<0.05)$ than the duration of gestation in swine that farrowed during cyclonic summer or anticyclonic autumn weather classes.

A further group of animals was added to the two groups described above, giving the following three groups: (1) with parturitions as forecast after 114 or 115 days; (2) with a gestation period of > 115 days; and (3) with a gestation period of < 114 days. Compared with the statistically expected number, fewer gestation periods < 114 days were recorded in anticyclonic winter weather classes. In cyclonic spring and autumn weather classes, fewer parturitions on time (114 or 115 days) were registered, while more gestation periods $>115$ days as well as those $<114$ days were observed. Cyclonic summer weather classes coincided with more parturitions after short gestation periods ( $<114$ days) and less parturitions after long gestation periods ( $>115$ days). Anticyclonic autumn weather classes were correlated much less frequently with extended gestation periods, but more often than expected with parturitions on time and reduced gestation periods $(P<0.05)$. As already observed in cattle, frontal passages on 
the day of parturition had no effect on gestation periods in swine.

The weather situation on the day before farrowing exerted an influence on the gestation period: cyclonic $G$ autumn weather coincided with a gestation period reduced by 0.95 days, while anticyclonic winter and spring weather situations coincided with a gestation period extended by 0.98 and 1.12 days, respectively $(P<0.05)$. Another form of interference by weather situations on the day before parturition on the gestation period was found. Sows that farrowed after anticyclonic winter weather classes and cyclonic spring weather classes had more extended gestation periods ( $\geq 115$ days) and fewer reduced gestation periods ( $\leq 114$ days) than expected $(P<0.05)$. Cyclonic $G$ spring weather conditions coincided with an extremely large number of prolonged gestation periods $>115$ days $(P<0.05)$. In cyclonic $K$ autumn weather situations, however, on the day before farrowing, there was a trend towards reduced gestation periods $(P<0.05)$. Frontal passages had no effect on the duration of gestation. Furthermore, there were no correlations between either weather situations or frontal passages on the day after parturition and the duration of gestation in swine.

Correlation of the expulsion period with the weather situations. The duration of parturition on days with cyclonic $G$ weather situations (average of $6.95 \mathrm{~h}$ ) compared with the duration of parturition on days with anticyclonic $G$ weather situations (average of $5.41 \mathrm{~h}$ ) was significantly prolonged $(P<0.01)$ by $1.49 \mathrm{~h}$ (Fig. 4). All other meteorological events had no statistically significant effect on the duration of parturition.

\section{Discussion}

Literature on veterinary obstetrics has so far lacked studies on correlations betweeen obstetrical and meteorological events. In humans Schaller et al. (1985, 1989) showed that there is significant correlation between obstetrical data (e.g. delivery, membrane rupture and the EPH-gestosis) and meteorological events. Humans and domestic animals have in common a genetically determined gestation period. However, although a normal duration of gestation can be defined, there is no such thing as 'normal' weather. In veterinary obstetrics, as opposed to human obstetrics, we can take advantage of knowing the exact date of insemination. It is also favourable that in domestic animals (in contrast to humans) no psychosocial or socioeconomic factors have to be considered. Therefore, maintaining the respective species at the model farm of the Veterinary University of Vienna under standardized conditions led to normalized results. Since only limited male breeding stock in the cattle and swine were selected for breeding, genetic influences on the obstetric parameters were kept to a minimum, which led to a more homogeneous evaluation of the data.

To correlate obstetrical data with the three general weather conditions G (no defined pressure gradient), $C$ (current weather) and $K$ (central weather) and ignoring the cyclone and anticyclone influence is critical from the meteorologist's viewpoint. While current weather situations $(C)$ and situations of no defined pressure gradient $(G)$ have almost equivalent effects in cyclonic and anticyclonic conditions, there is no common (a)

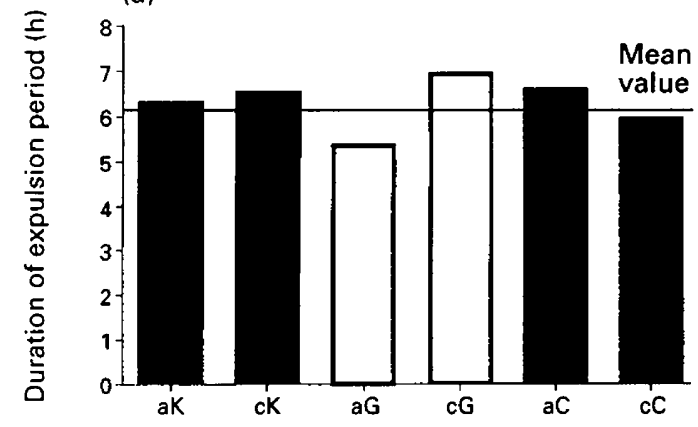

(b)

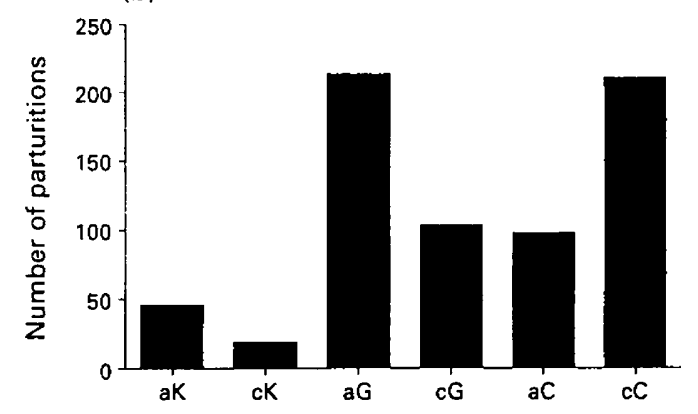

Fig. 4. The mean deviation from the average to the duration of the expulsion periods in swine when the individual weather situations (Table 1) during parturition were considered. (a) The open columns indicate a significant difference in the expulsion period of swine during anticyclonic $G$ and cyclonic $G$ weather situations (the closed columns indicate no statistical significance). (b) The absolute distribution of swine parturitions among the individual weather situations. a: anticyclone; c: cyclone; $C$ : current (dynamic) weather situation; $G$ : weather situation of no defined pressure gradients; $\mathrm{K}$ : central weather situation.

denominator for cyclonic and anticyclonic central weather situations (K) from the meteorological point of view. The physical and atmospherical properties of these two types of central weather situation are of the most striking contrast possible. Since the area we surveyed is centred within the dominant weather events only in central weather situations, the two classes of cyclonic and anticyclonic central weather, from the biological point of view, are both probably times of great influence on the autonomic nervous system.

Marktl and Machalek (1983) reviewed and summarized different results from medical-meteorological interactions. They divided the effect of the weather on biological parameters into five major areas. Four of them, the photoactive (duration and intensity of light), the thermic (temperature), the airchemical (concentration of ammonia and nitrogen) and the air-electric (concentration of positive or negative ionization of the air) components were effectively eliminated by maintaining swine in airconditioned housing. Therefore, our data are most likely the result of the fifth area, the so-called 'neurotrope active complex'. Marktl and Machalek (1983) considered this to be the reaction of the autonomic nervous system to weather components such as humidity, air pressure and air movement. With respect to this model proposed by Marktl and Machalek, 
the less impressive correlations that we have noted here in cattle could be the result of neutralizing effects of the different areas mentioned above, since the stabling conditions for this species would have definitely exposed the animals to all five components.

The onset of labour is probably caused, or at least accompanied by, an increase in the concentration of glucocorticoids in cattle and swine (Hoffmann et al., 1979). This event occurs at variable times (2-5 weeks) before parturition in individual animals (Stabenfeld et al., 1970; Ash et al., 1973; Robertson and King, 1974), and initiates a cascade of important endocrine mechanisms relevant for birth (Eissa and El-Belely, 1990). There have been reports on the relationship between weather situations and the concentration of corticosteroids (Collins and Weiner, 1968; Schmidt-Kessen and Hornberger, 1978), but even though adrenocortical activity was affected, the mode of action is unknown. Furthermore, because the results presented here relate only to the short period around birth, it is not possible to establish a theory on the correlation of weather with endocrine mechanisms in pregnancy, especially since the hormonal cascade begins much earlier. However, within $24 \mathrm{~h}$ before birth myometrial activity is not only affected by hormonal patterns specific for gestation or parturition, but also by the autonomic nervous system, especially the secretion of catecholamines by the adrenal medulla (Rüsse, 1965; Naaktgeboren and Bontekoe, 1976; Marktl and Machalek, 1983). The autonomic nervous system is affected by environmental factors and interferes with the myometrial motility to slow down (sympathetic activation) or promote (parasympathetic activation) parturition (Hauser, 1960; Rüsse, 1965; Naaktgeboren and Slijper, 1977; Naaktgeboren and Bontekoe, 1976; Fitz, 1981; Marktl and Machalek, 1983). One possible explanation of some of the effects of weather on parturition is that environmental factors such as temperature (Collins and Weiner, 1968; Reinhardt et al., 1976), air pressure (SchmidtKessen et al., 1976) or humidity (Schmidt-Kessen and Hornberger, 1978) influence the productive and secretory activity of the adrenal medulla, and by doing so interfere with parturition.

In the present study it was demonstrated that meteorological events can influence the gestation period or parturition. In cattle, a reduction of the gestation period by almost 5 days occurs in long-lasting weather conditions. It seems that cattle make use of a continuous weather situation for calving. This does not occur in swine. Reductions and extensions of gestation periods of almost $I$ day during the most different meteorological events could be considered as an indication of a higher sensitivity towards the weather in swine than in cattle. Of note in this context is the extension of the duration of the expulsion period in sows by $1.5 \mathrm{~h}$ during cyclonic $G$ weather situations ('inclement weather') compared with that during anticyclonic $G$ weather situations ('good weather'). Incidentally, the study also supports the well-known fact that a reduction in the duration of gestation in cattle is accompanied by an extended period for the discharge of placentae (Arbeiter, 1983; Grunert, 1983). In this respect, weather seems to be unimportant. In agreement with the results of Schaller et al. $(1985,1989)$, the data demonstrate that front passages on the day before, during, and the day after parturition have no measurable influence on obstetrical events.

\section{References}

Adiabatenblätter Teil A (1980-1989) Termine OOOOUTC und 12000TC von Wien-Hohe Warte (international synop identification $=11035$ )

Arbeiter K (1983) Manipulation der Geburt Wiener Tierärztliche Monatsschrift $70283-286$

Arbeiter K and Holler W (1980) Zur Steuerung der Geburt: Über den Einfluß der Kortikoide Flumethason/Dexamethason und des $\beta$-Mimetikums Planipart ${ }^{\mathbb{B}}$ auf Geburt, Purerperium und erneute Konzeption beim Rind Deutsche Tierärztliche Wochenschrift 89 249-251

Arthur GH, Noakes DE and Pearson H (eds) (1989) Pregnancy and parturition. In Veterinary Reproduction and Obstetrics (Theriogenology) (6th Edn) pp 283-286. Baillière Tindall, London

Ash RW, Banks P, Bailes G, Broad S and Heap RB (1973) Plasma oestrogen, progesterone and corticoid concentrations in the pregnant, parturient and lactating sow Joumal of Reproduction and Ferility 33 359-360

Caldwell RW, Whittier JC, Smith MF, Morrow RW and Anthony RV (1990) Parturition in beef cows following administration of porcine relaxin at ten days prepartum Theriogenology $33613-625$

Clegg TM (1959) Factors affecting gestation length and parturition. In Reproduction in Domestic Animals Vol. I pp 509-538 Eds HH Cole and PT Cupps. Academic Press, New York, London

Collins KJ and Weiner IS (1968) Endocrinological aspects of exposure to high environmental temperatures Physiological Reviews 48 785-837

Comline RS, Hall LW, Lavelle RB, Nathanielsz PW and Silver M (1974) Parturition in the cow: endocrine changes in animals with chronically implanted catheters in the foetal and maternal circulations Journal of Endocrinology 63 451-472

Diehl JR, Baker DH and Dziuk PJ (1977) Effect of PGF2 $\alpha$ on sow and litter performance during and following parturition Joumal of Animal Science 44 89-94

Edqvist LE, Ekmann L, Gustafsson B and Johansson EDB (1973) Peripheral plasma levels of oestrogens and progesterone during late pregnancy Acta Endocrinologia 72 81-88

Eissa HM and El-Belely MS (1990) Sequential changes in plasma progesterone, total oestrogens and corticosteroids in the cow throughout pregnancy and around parturition British Veterinary Joumal 146 24-29

First NL and Bosc MJ (1979) Proposed mechanisms controlling parturition and the induction of parturition in swine Journal of Animal Science 48 1408-1421

Fitz R (1981) Catecholamine und deren Metaboliten im Urin von Rindern bei normalen und gestörten Geburten Inaugurual Dissertation München

Grunert E (1983) Ätiologie, Pathogenese und Therapie des Nachgeburtsverhalten beim Rind Wiener Tierärztiche Monatsschrift 70 230-235

Grunert E (1993) Die normale Geburt. In Richter/Götze Tiergeburtshilfe, 4. Auft. pp 83-102 Eds E Grunert and K Arbeiter. Paul-Parey, Berlin und Hamburg

Hauser GA (1960) Die Rolle des neurovegativen Nervensystems in der Gynäkologie und Geburtshilfe Fortschritte in der Geburtshilfe und Gynäkologie 10 17-260

Hoffmann B, Wagner WC, Rattenberger E and Schmidt J (1977) Endocrine relationships during late gestation and parturition in the cow. In The Fetus and Birth (Ciba Foundation Symposium 47) pp 107-125 Ciba, Amsterdam, Oxford, New York

Hoffmann B, Schmidt J and Schallenberger J (1979) Hormonal mechanisms involved in control of parturition in cows. In Calving Problems and Early Viability of the Calf (Current Topics in Veterinary Medicine and Science, Vol. 4) pp 263-281 Eds B Hoffmann, IL Mason and J Schmidt. Martinus Nijhoff Publishers, The Hague, Boston, London

Kiesling DO, Price EA and Meredith S (1987) Use of flumethasone, clenbuterol and oxytocin to control time of lambing Journal of Animal Science 65422

Lindell JO, Edquist LE and Gustafsson B (1981) Oophorectomy during different stages of pregnancy in the cow Acta Veterinaria Scandinavica 22 553-565

Marktl W and Machalek A (1983) Einfluß meteorologischer Vorgänge auf gesunde und kranke Menschen. In Österreichische Gesellschaft zur Förderung medizinisch-meteorologischer Forschung Eds W Marktl and A Machalek. Eigenverlag, Wien

Musah AI, Schwabe C and Anderson LL (1987) Acute decrease in progesterone and increase in estrogen secretion caused by relaxin during late pregnancy in beef heifers Endocrinology 120 317-324

Naaktgeboren C and Bontekoe EHM (1976) Vergleichend - geburtskundliche Betrachtungen und experimenteile Untersuchungen über pyschosomatische Störungen der Schwangerschaft und des Geburtsablaufes Zeitschrift für Tierzüchtung und Züchtungsbiologie 93 264-320 
Naaktgeboren C and Slijper J (eds) (1970) Biologie der Geburt pp 148-155. Paul Parey, Berlin und Hamburg

Nara BS, Welk FA, Rutherford JE, Sherwood OD and First NL (1982) Effect of relaxin on parturition and frequency of live births in pigs Journal of Reproduction and Fertility 66 359-365

Orlansky J (1975) A rational subdivision of scales for atmospheric processes Bulletin of the American Meteorologists Society 56 527-530

Pimentel CA, Vijayakumar R, Weston PG, Pimentel MS, Wagner WC and Hixon JE (1986) Effects of estrone infusion on secretion of $F$ series prostaglandins and on function of the corpus luteum during late gestation in cattle American Joumal of Veterinary Research 47 1972-1977

Randall GCB (1990) Induction of parturition in pigs: short term effects of prostaglandin $\mathrm{F}_{2 \alpha}$ on chronically catheterised fetuses at term The Veterinary Record 126 61-63

Randall GCB, Taverene MAM, Challis JRG, Kendall JZ and Tsang BK (1986) Interrelationships between endocrine changes in peripheral and uterinevenous blood and uterine activity at parturition in the pig Animal Reproduction Science 11 283-294

Randerson D (1976) Overview of regional-scale numerical models Bulletin of the American Meteorologists Society 57 797-804

Reinhardt H, Kendel K and Schmidt-Kessen W (1976) Die Adaption des Menschen an thermisch gestörte Nächte Zentralblatt für physiologische Medizin 5 60-66

Robertson HA (1974) Changes in the concentration of unconjugated oestrone, oestradiol-17 $\alpha$ and oestradiol $17 \beta$ in the maternal plasma of the pregnant cow in relation to the initiation of parturition and lactation journal of Reproduction and Fertility 36 1-7

Robertson HA and King GJ (1974) Plasma concentrations of progesterone, oestrone, oestradiol $17 \beta$ and oestrone sulphate in the pig at implantation during pregnancy and at parturition Journal of Reproduction and Fertility $\mathbf{4 0}$ 133-141

Rüsse M (1965) Der Geburtsablauf beim Rind. Eine Betrachtung des funktionellen Geschehens bei der Normalgeburt Archiv für Experimentelle Veterinärmedizin $19763-870$
Schaller A, Pfersmann Ch and Machalek A (1985) Korrelation von Wehenbeginn, Blasensprung und Geburt mit meteorologischen Ereignissen Zentralblatt für Geburtshilfe und Perinatologie 189 202-209

Schaller A, Radivojevic K and Sabo P (1989) Korrelation von EPH-Gestose mit meteorologischen Ereignissen Zentralblatt für Geburtshilfe und Perinatologie 193 105-114

Schmidt-Kessen W and Hornberger G (1978) Einfluß verschiedener bioklimatischer Bedingungen während des Nachtschlafes auf die Katecholaminausscheidung im Urin Zeitschrift für angewandte Bäder und Klimaheilkunde 25 29-42

Schmidt-Kessen W, Reinhardt H and Kendel K (1976) Comparative studies on night sleep at $3450 \mathrm{~m}$ altitude in alpine mountains and in low pressure chamber Bulletin of the American Meteorologists Society $\mathbf{5 7} 282$

Stabenfeld GH, Osburn BI and Ewing LL (1970) Peripheral plasma progesterone levels in the cow during pregnancy and parturition American Joumal of Physiology 218 571-575

Steinhauser F, Eckel $\mathbf{O}$ and Sauberer F (1955) Klima und Bioklima von Wien, Teil I, Österreichische Gesellschaft für Meteorologie. Eigenverlag, Wien

Steinhauser F, Eckel $\mathbf{O}$ and Sauberer F (1957) Klima und Bioklima von Wien, Teil II, Österreichische Gesellschaft für Meteorologie. Eigenverlag, Wien

Täglicher Wetterbericht der Zentralanstalt für Meteorologie und Geodynamik, Jahrgang 95-104, Nr 1-365 (366)

Watts AD, Flint APF, Foxcroft GR and Porter DG (1988) Plasma steroids, relaxin and dihydro-keto-prostaglandin $\mathrm{F}_{2 a}$ changes in the mining in relation to myometrial electrical and mechanical activity in the pre-partum period Journal of Reproduction and Fertility 83 553-564

Wendorf GL, Lawyer MS and First NL (1983) Role of the adrenals in the maintenance of pregnancy in cows Joumal of Reproduction and Fertility $\mathbf{6 8}$ 281-287

Zerobin K and Kündig H (1980) The control of myometrial functions during parturition with a $\beta 2$-mimetic compound, Planipart ${ }^{(\$)}$ Theriogenology 14 $21-28$ 